\title{
Use of crystalline waterproofing to reduce capillary porosity in concrete
}

\author{
Vanessa Giaretton Cappellesso ${ }^{1} \cdot$ Natália dos Santos Petry $^{2} \cdot$ \\ Denise Carpena Coitinho Dal Molin ${ }^{2}$ Angela Borges Masuero ${ }^{2}$
}

Received: 30 June 2016/Accepted: 14 October 2016/Published online: 25 October 2016

(C) Springer International Publishing Switzerland 2016

\begin{abstract}
The use of different technologies have contributed to the increase in durability facing the aggressive agents that damage the concrete structures. Therefore, it is possible to reduce the capillary porosity in concrete lowering the ratio water/binder; using pozzolan, hydrophobic or waterproofing products in the mixture; applying hydrophobic products or waterproofing in the concrete surface; replacing pure cements for compounds cements, pozzolanic cements or cements with blast furnace slag; among other actions. The waterproofing has the function to prevent the water or fluid passage in liquid or steam state, thereby protecting structures. The waterproofing creates a barrier when coating is applied to close surface pores with the aim of preventing the water pervasion by any transport mechanism. This paper has evaluated the use of crystalline waterproofing as admixtures, as well as a coating, sanding and no-sanding, in order to know the benefits it can bring to the concrete water absorption, comparing their performance with other concretes with or without silica fume admixture. Developed tests were: total absorption, under pressure water penetration $(30 \mathrm{kPa})$ and compressive strength test. The results have showed that the silica fume
\end{abstract}

Vanessa Giaretton Cappellesso

vgcappellesso@gmail.com

Natália dos Santos Petry

nataliapetry@yahoo.com.br

Denise Carpena Coitinho Dal Molin

dmolin@ufrgs.br

Angela Borges Masuero

angela.masuero@ufrgs.br

1 Federal University of Rio Grande do Sul (UFRGS)/Center for Innovation Oriented Building (NORIE), Porto Alegre, Brazil

2 UFRGS/NORIE, Porto Alegre, Brazil admixture is more efficient than the analyzed crystalline waterproofing, as it has contributed to the compressive strength increase and decrease of water absorption and penetration. The crystalline waterproofing admixture has contributed to compressive strength increase; however, there was also an increase in the absorption and penetration. On the other hand, the coating waterproofing has not influenced the compressive strength, but reduced absorption and penetration when sanded.

Keywords Concrete $\cdot$ Capillary porosity $\cdot$ Crystalline waterproofing $\cdot$ Impermeability

\section{Introduction}

The concrete structures durability has been in focus in recent years. During the second half of the 20th century there was an increase in damage caused by the deterioration of buildings; repairs of these concrete buildings have nowadays been intensified and also increased the concern of its durability [1]. Problems related to this issue tend to aggravate, as many buildings constructed in the past decades are now more than 40-years-old, thus resulting in cost increase of maintenance and repair, which is the greatest concern for project settings that increase the structures durability [2].

Due to physical, chemical and mechanical characteristics the concrete used in different environments gets exposed to several harmful agents, that compromise its durability [3]. The assessment of durability is related with the expected product performance, in which some factors are decisive for its good understanding, is set, knowing the material composition and its behavior allows to assess changes caused by the product interaction with external aggressive agents and measure the damage over time [4]. 
To learn about the fluid transport mechanisms in concrete it important to understand the various deterioration forms that occur in these structures. Water is the main factor that negatively influences the concrete durability, and the rate of deterioration is intensified by the ease the water penetrates in this material [5]. Therefore, ensuring a concrete with low capillary porosity contributes to durability increase prolonging its service life.

There are four water transport mechanisms: permeability, gas diffusion, diffusion and ion migration, capillary, these act as pore size ranging from $10^{-2} \mathrm{~m}$ to $10^{-9} \mathrm{~m} \mathrm{[6].} \mathrm{The} \mathrm{pore}$ mesh is a tangle of channels and capillaries, which in most cases do not communicate with each other, and allow the concrete to introduce impermeability to liquids and gases [7].

Several factors influence the concrete durability, like physical and chemical effects that influence the reduction of the concrete structures durability [5]. Durability is not an intrinsic property of the material, but it is related to its performance under certain environmental conditions [8].

Water is the main agent of degradation of solid materials, however it is essential in the production of concrete and responsible for the cement hydration reactions [5].

The water and other fluids permeability in concrete can result in degradation, thus reducing the concrete structures service life. Currently various studies have been conducted, in order to produce and test waterproofing additives to increase these elements service life [9]. In this way the repair and maintenance costs of concrete structures could be avoided.

Prevent fluids from entering the concrete is essential to ensure durability. This can be achieved with lower capillary porosity by decreasing the ratio water/binder, using pozzolan or waterproofing products in the mixture, or applying waterproofing products in the concrete surface.

The waterproofing has the function to prevent the water or fluid passage in liquid or steam state, thereby protecting the structures. The waterproofing creates a barrier when the coating is applied, to close surface pores with the aim of preventing the water penetration by any transport mechanism. Some waterproofing can also be used as admixture in the mixture, with the objective of decreasing the capillary porosity of the concrete, making it less porous and more resistant to aggressive agents [10].

Waterproofing products are used in almost all buildings to ensure the tightness and impermeability in structures such as foundations, basements, wet and exposed to inclement weather areas, slabs, pools, among others, providing for an increase in constructions service life. This slows or even mitigate deterioration processes, as a consequence the durability increase. Crystalline waterproofing is considered a pore plugged protection system, in which, as explained, pores are closed [10]. The author declares that, because of the silicatebased substances present in the product, and by its penetration in concrete they react with by-products, in particular calcium hydroxide, and form crystals that cause the pores sealing.

Due to the waterproofing crystallization property, it has the capability to block the pores and capillaries, as well as fill the microcracks turning it into a waterproof concrete. Application of an impermeable coating on the concrete surface can prevent aggressive agents penetration; however, an impermeable layer does not allow even water evaporation present in the concrete. According to the author, a coating with good performance is one that has tight compaction and impermeability, but also allows the water evaporation in the concrete [10].

Currently, some studies are emerging related to the use of waterproofing products, however in both national and international literature the number of studies is reduced. Among the existing studies, it can be observed the change of the agents used in the base product (epoxy, polyurethane, silicate based compounds, cementitious materials, nano silica, among others). It was also observed that the products were tested in different matrices (conventional concrete, mortar, polymer concrete and bricks) and the form of use to make the waterproof material is varied (mixture of the agent in the cementitious compound, coating such as painting, dipping and spraying) [9].

Another study verified the influence of nano particles on the mortars mechanical properties, these were produced with nano- $-\mathrm{Fe}_{2} \mathrm{O}_{3}$ and nano- $\mathrm{SiO}_{2}$ admixtures, with which it could be concluded that the nano-particles helped to increase both the compressive and flexural strength. It could also be verified from the nano-particles microstructure analysis that it not only acts as filler effect, but also as an activator of hydration and improvement of cement paste microstructure [11].

To evaluate the crystalline waterproofing products efficiency, the most commonly used tests are those which measure water absorption and chloride penetration [9]. The purpose of this study is to analyze the use of a crystalline waterproofing, as coating and as admixture, comparing their performance with other concretes with or without silica fume admixture. The tests performed were: total absorption-NBR 9778 (ABNT) [12], under pressure water penetration (30 kPa) with measurement of wet area and the compressive strength test-NBR 5739 (ABNT) [13], these tests were conducted in order to check the capillary porosity concrete.

\section{Materials and methods}

\subsection{Materials}

\subsubsection{Cement}

The material used was Portland pozzolanic cement. According to NBR 5736 (ABNT) [14], pozzolanic 
material content is between 15 and $50 \%$, with a tolerance of $5 \%$ of limestone filler and the remaining of d clinker and calcium sulphate. This cement is equivalent to type IP according to ASTM C 595 [15]. Concrete made with this binder have longer service life when compared to other types of cement keeping the same water/binder, which is why it was chosen for this study. The existence of pozzolans composition causes the pozzolanic reaction, which is slow and continuous, forming resistant products by calcium hydroxide consumption, which entails a decrease of porosity concrete [16].

The cement bulk specific gravity was determined in the laboratory according to NBR NM 23 (ABNT) [17] and resulted in $2.59 \mathrm{~g} / \mathrm{cm}^{3}$. Chemical, physical and mechanical characteristics of the cement were provided by the manufacturer and are presented in Tables 1 and 2, are shown also in tables regulatory limits according NBR 5736 (ABNT) [15].

\subsubsection{Aggregates}

The aggregates were characterized according to sieve analysis by NBR NM 248 (ABNT) [18] and for determining the bulk specific gravity, it was used the NBR NM 52 (ABNT) [19] for fine aggregate and the NBR NM 53 (ABNT) [20] for coarse aggregate.

2.1.2.1 Fine aggregate The fine aggregate used was quartz sand, whose particles have fineness modulus of 2.28. The sand bulk specific gravity, is $2.58 \mathrm{~g} / \mathrm{cm}^{3}$. In Table 3 it can be seen the percentage retained on each normal series sieve and other information. Figure 1 shows the sieve distribution of fine aggregate.

2.1.2.2 Coarse aggregate The chosen coarse aggregate was basalt and was applied in two different granulometries. In Table 4 it can be seen the percentage retained on each normal range and intermediate range sieve for coarse aggregates. Figure 2 shows sieve distribution and in Table 5 the features found for the coarse aggregate use are described.

Table 1 Chemical composition of cement (source: adapted from INTERCEMENT, 2016)

\begin{tabular}{lcl}
\hline Characteristics evaluated $(\%)$ & Results & Normative limits \\
\hline Magnesium oxide $(\mathrm{MgO})$ & 4.70 & $\leq 6.5$ \\
Trioxide sulphur $\left(\mathrm{SO}_{3}\right)$ & 1.80 & $\leq 4.0$ \\
Loss on ignition & 2.60 & $\leq 4.5$ \\
Insoluble & 40.70 & - \\
\hline
\end{tabular}

Table 2 Physical and mechanical characterization of cement (source: adapted from INTERCEMENT, 2016)

\begin{tabular}{|c|c|c|c|}
\hline \multicolumn{2}{|l|}{ Characteristics evaluated } & Results & Normative limits \\
\hline \multicolumn{2}{|l|}{ Fineness \#200 } & 0.40 & $\leq 8.0$ \\
\hline \multicolumn{2}{|l|}{ Fineness \#325 } & 2.00 & - \\
\hline \multicolumn{2}{|c|}{ Setting times start (h:min) } & $5: 55$ & $\geq 1$ \\
\hline \multicolumn{2}{|c|}{ Setting times end (h:min) } & $8: 15$ & $\leq 12$ \\
\hline \multicolumn{2}{|l|}{ Specific area $\left(\mathrm{cm}^{2} / \mathrm{g}\right)$} & 4900 & - \\
\hline \multirow[t]{3}{*}{ Compressive strength } & Day $01(\mathrm{MPa})$ & 17.7 & $\geq 10.0$ \\
\hline & Day $07(\mathrm{MPa})$ & 22.8 & $\geq 20.0$ \\
\hline & Day $28(\mathrm{MPa})$ & 36.2 & $\geq 32.0$ \\
\hline
\end{tabular}

\subsubsection{Water}

The water used in this study for molding the specimens comes from the public supply of the city of Porto Alegre, Rio Grande do Sul, Brazil.

\subsubsection{Admixtures}

It was used in this study two admixtures types. The silica fume was selected to serve as a comparison, since this is usually applied at concrete with the aim of reducing the capillary porosity. The crystalline waterproofing is the chosen material to be tested in this study.

2.1.4.1 Silica fume The silica fume confers specific properties to concrete, such as low permeability, low hydration heat, increase in mechanical strength, resistance to sulfate attack, durability increase, alkali-aggregate reaction minimizing, among others. Since this is a special pozzolan chemically compound type with $\mathrm{SiO}_{2}(>86 \%)$, specially in glassy and amorphous phase, it may also be found crystalline compounds as cristobalite and silicon carbide. The silica fume bulk specific gravity was determined in laboratory according to NBR NM 23 (ABNT) [17] and resulted in $2.20 \mathrm{~g} / \mathrm{cm}^{3}$. The chemical characterization of the material was performed using X-ray fluorescence assay in Lacer/UFRGS laboratory, whose results are shown in Table 6.

2.1.4.2 Crystalline waterproofing The crystalline waterproofing used as filler in this study was provided in $25 \mathrm{~kg}$ packaging and is composed of Portland cement (40 to $70 \%$ ), quartz sand (5 to $10 \%$ ) and active chemicals (10 to $30 \%$ ), according to manufacturer's description. The chemicals react with the moisture in fresh concrete and with cement hydration products, which result in an insoluble crystalline structure in concrete pores and capillaries. 
Table 3 Percentage retained in the normal range sieves for fine aggregate

\begin{tabular}{|c|c|c|c|c|c|c|}
\hline \multirow[t]{4}{*}{ Grid size sieve } & \multicolumn{2}{|l|}{ Sample } & \multirow{2}{*}{\multicolumn{4}{|c|}{$\frac{\text { NBR } 7211(2005)[21]}{\text { Accumulated retained (\%)-in mass }}$}} \\
\hline & \multirow[t]{3}{*}{ Average retained $(\%)$} & \multirow[t]{3}{*}{ Average accumulated retained (\%) } & & & & \\
\hline & & & \multicolumn{2}{|l|}{ Lower limits } & \multicolumn{2}{|c|}{ Upper limits } \\
\hline & & & Useable area & Great area & Great area & Useable area \\
\hline 4.75 & 2 & 2 & 0 & 10 & 20 & 25 \\
\hline 2.36 & 5 & 7 & 5 & 20 & 30 & 50 \\
\hline 1.18 & 9 & 16 & 15 & 35 & 55 & 70 \\
\hline 0.6 & 17 & 33 & 50 & 65 & 85 & 95 \\
\hline 0.3 & 41 & 73 & 85 & 90 & 95 & 100 \\
\hline 0.15 & 24 & 97 & 100 & 100 & 100 & 100 \\
\hline Fund & 3 & 100 & - & - & - & - \\
\hline \multicolumn{3}{|c|}{ Fineness modulus } & & 2.28 & & \\
\hline \multicolumn{3}{|c|}{ Maximum size $(\mathrm{mm})$} & & 4.75 & & \\
\hline \multicolumn{3}{|c|}{ Bulk specific gravity $\left(\mathrm{g} / \mathrm{cm}^{3}\right)$} & & 2.58 & & \\
\hline
\end{tabular}

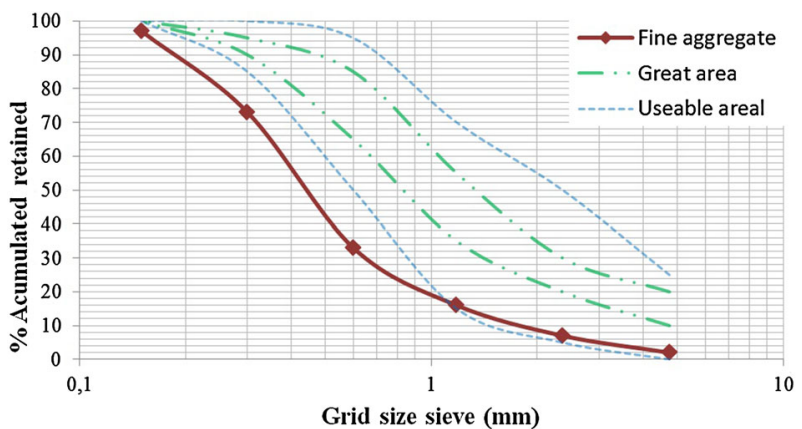

Fig. 1 Distribution according to fine aggregate sieve

The physicochemical properties are shown in Table 7 as the product data sheet.

The proportion used of the waterproofing admixture is 0.8 , the lowest recommended value was chosed to analyze the product in its most critical situation. The use of this material aims to permanently seal the concrete against water and other liquids penetration, thus contributing to protection against harsh environmental conditions due its low permeability. This product is used in structures such as reservoirs, water and effluent treatment plants, tunnels, foundations, and other buildings requiring waterproof concrete.

\subsubsection{Chemical admixtures}

The chemical admixtures employed in the mixture were assigned according proportioning provided by a concrete service company for conventional buildings, that do not require high strength at early ages. The same proportion of two additives, an additive plasticizer polyfunctional waterreducing and another superplasticizer. These chemical admixtures are discriminated according to ASTM C 494 as type $\mathrm{A}$ and $\mathrm{F}$. The characteristics were obtained from the manufacturer and are presented in Table 8.

Both chemical admixtures provide benefits to hardened concrete, like reducing the mixing water, maintaining consistency, increasing fluidity, facilitating the densification and the launch, aside from increasing the concrete cohesion. As for the hardened concrete, because it requires

Table 4 Percentage retained in sieves for coarse aggregates

\begin{tabular}{|c|c|c|c|c|}
\hline \multirow[t]{2}{*}{ Sieve $(\mathrm{mm})$} & \multicolumn{2}{|c|}{ Percentage retained $(\%)$ coarse aggregate $\mathrm{MZ}=12.5 \mathrm{~mm}$} & \multicolumn{2}{|c|}{ Percentage retained $(\%)$ coarse aggregate $\mathrm{MZ}=25 \mathrm{~mm}$} \\
\hline & Individual & Accumulated & Individual & Accumulated \\
\hline 25 & 0.0 & 0.0 & 0.0 & 0.0 \\
\hline 19 & 0.0 & 0.0 & 20.9 & 20.9 \\
\hline 12.5 & 0.8 & 0.8 & 76.1 & 96.9 \\
\hline 9.5 & 13.6 & 14.4 & 3.0 & 99.9 \\
\hline 6.3 & 47.2 & 61.6 & 0.1 & 100.0 \\
\hline Fund & 38.4 & 100.0 & 0.0 & 100.0 \\
\hline
\end{tabular}




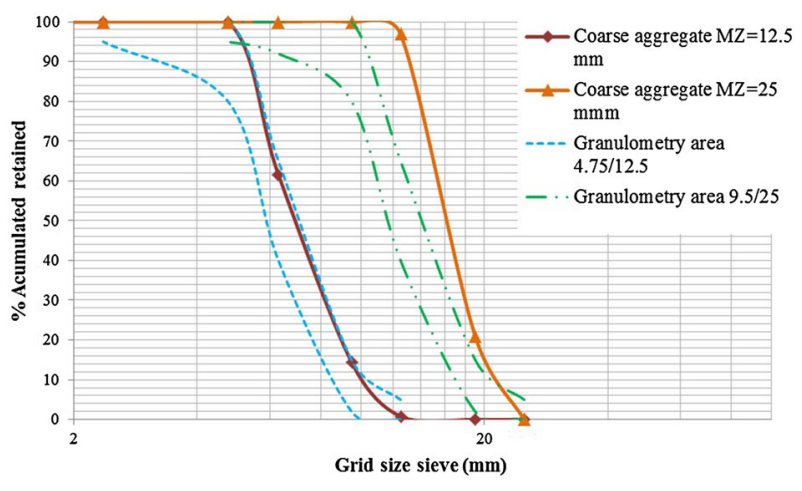

Fig. 2 Distribution according to coarse aggregate sieve

Table 5 Physical characterization of coarse aggregates

\begin{tabular}{|c|c|c|}
\hline Characterization & $\begin{array}{l}\text { Coarse } \\
\text { aggregate } \\
\mathrm{MZ}=12.5 \mathrm{~mm}\end{array}$ & $\begin{array}{l}\text { Coarse } \\
\text { aggregate } \\
\mathrm{MZ}=25 \mathrm{~mm}\end{array}$ \\
\hline Maximum size (mm) & 12.5 & 25 \\
\hline Fineness modulus & 6.15 & 7.21 \\
\hline $\begin{array}{l}\text { Bulk specific gravity of dry } \\
\text { aggregate }\left(\mathrm{g} / \mathrm{cm}^{3}\right)\end{array}$ & 2.95 & 2.91 \\
\hline $\begin{array}{l}\text { Bulk specific gravity of saturated } \\
\text { aggregate surface dry }\left(\mathrm{g} / \mathrm{cm}^{3}\right)\end{array}$ & 2.88 & 2.87 \\
\hline $\begin{array}{l}\text { Bulk specific gravity apparent } \\
\left(\mathrm{g} / \mathrm{cm}^{3}\right)\end{array}$ & 2.83 & 2.85 \\
\hline Water absorption (\%) & 1.43 & 0.66 \\
\hline
\end{tabular}

less water in the mixture, it provides great mechanical strength, decreases the permeability, retractions and cracks of plastic origin; thereby enhancing the durability.

\subsubsection{Coating}

The coating was carried out with the same crystalline waterproofing employed as admixture; however, this is appropriate for surface treatment performing. The goal of this product is waterproof concrete. This consists in Portland cement (10 to 50\%), quartz sand (10 to 40\%) and active chemicals (30 to $60 \%$ ). It only needs to be mixed with water in the ratio 5:2.5 (crystalline waterproofing: water) to react and than be applied to the concrete surface. This proportion is recommended for manual use, in order to fill pores and cracks, to prevent water from entering even under pressure, and to ensure the steam passage. Its use is indicated for structures that require great durability and are put through aggressive agents, such as water reservoirs, dams, water and effluent treatment plants, parking, foundations, tunnels, among others, since the product can be applied to both positive and negative side concrete.
Table 6 Silica fume chemical composition

\begin{tabular}{lr}
\hline Chemical compounds & \multicolumn{1}{c}{$(\%)$} \\
\hline $\mathrm{Al}_{2} \mathrm{O}_{3}$ & 0.20 \\
$\mathrm{SiO}_{2}$ & 92.36 \\
$\mathrm{Fe}_{2} \mathrm{O}_{3}$ & 0.14 \\
$\mathrm{CO}_{2}$ & 5.06 \\
$\mathrm{MgO}$ & 0.24 \\
$\mathrm{SO}_{3}$ & 0.15 \\
$\mathrm{~K}_{2} \mathrm{O}$ & 0.86 \\
$\mathrm{MnO}$ & 0.03 \\
$\mathrm{P}_{2} \mathrm{O}_{5}$ & 0.11 \\
$\mathrm{CaO}$ & 0.77 \\
$\mathrm{Na}_{2} \mathrm{O}$ & 0.06 \\
\hline
\end{tabular}

Table 7 Physicochemical characteristics of the crystalline waterproofing admixture (source: adapted from the manufacturer, 2016)

\begin{tabular}{ll}
\hline Characteristics & \\
\hline Appearance & Gray powder \\
Odor & Odorless \\
Physical state & Solid (powder) \\
$\mathrm{pH}$ solution & $10-13$ \\
Density $\left(\mathrm{g} / \mathrm{cm}^{3}\right)$ & 2.920 \\
Dosage $(\%)$ on the cement weight & $0.8-1.0$
\end{tabular}

In this study, coating was made in concrete without admixtures to test only the performance of crystalline waterproofing applied as paint, in two coats; according to operational instructions, the second coat must be applied before the primer dried. Furthermore, the manufacturer claims that the product develops the same performance if is the sample was sanding or not; therefore, specimens were tested with the coating being sanded, and the painted without the sanding. Figure 3 illustrates the product application and visual appearance with the crystalline waterproofing coating.

\subsection{Experimental program}

To achieve the objectives proposed in this paper, an experimental program was developed, that enabled the analysis of the concrete behavior subjected to different treatments, keeping the same proportions. From the proportions employed for all concrete types tested, four different variations were developed and those compared with each other and compared with a reference concrete, which does not have admixtures and coating. The other four types are: concrete crystalline waterproofing coating applied as paint, concrete crystalline waterproofing coating applied as paint which is sanding, concrete with crystalline 
Table 8 Physicochemical characteristics of the chemical admixtures (source: adapted from Grace Construction Products, 2016)

\begin{tabular}{lll}
\hline Characteristics & Chemical admixtures & \\
\cline { 2 - 3 } & Polyfunctional & Superplasticizer \\
\hline Chemical base & Lignosulphonate & Polycarboxylate \\
Aspect & Liquid & Liquid \\
Color & Dark brown & Light brown \\
Density $\left(\mathrm{g} / \mathrm{cm}^{3}\right)$ & $1.160 \mp 0.02$ & $1.095 \mp 0.02$ \\
Solids $(\%)$ & $28.0 \mp 2$ & $40.0 \mp 2$ \\
Dosage $(\%)$ on the cement weight & $0.6-1.0$ & $0.3-1.2$ \\
\hline
\end{tabular}

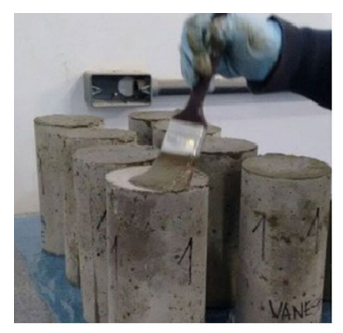

(a)

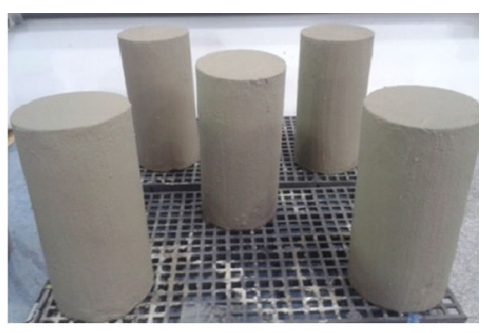

(b)
Fig. 3 Crystalline waterproofing coating a applying the product, b specimens visual appearance with crystalline waterproofing coating

waterproofing admixture and concrete with silica fume admixture.

\subsubsection{Concrete production}

The materials proportions employed are usually used in buildings made in the region of Porto Alegre, and is estimated to get $\mathrm{f}_{\mathrm{ck}}$ of $40 \mathrm{MPa}$. The proportions are described in Table 9, which shows the proportions of each material used.

The specimens molding was performed according to NBR 5738 (ABNT) [22]. After mixing the materials, sought consistency specified $200 \pm 30 \mathrm{~mm}$ through the implementation Slump test for consistency determination, as required by NBR NM 67 (ABNT) [23], maintaining the parameter fixed.

They were made twenty-six specimens of this reference concrete, eleven of those without coating (seven for compressive strength test and four for the absorption tests) and fifteen with coating (seven for compressive strength test and eight for the absorption tests, these eight only four passed sanding process). In these eleven there were molded specimens with crystalline waterproofing admixture (seven for the compressive strength test and four for the absorption tests). Finally, another eleven specimens were molded with silica fume admixture (seven for the compressive strength test and four for the absorption tests). Specimens were cylindrical with dimensions of $100 \mathrm{~mm}$ diameter by $200 \mathrm{~mm}$ height.
Table 9 Materials proportioning, in mass

\begin{tabular}{ll}
\hline Materials & Proportions \\
\hline Cement & 1 \\
Fine aggregate & 1.5 \\
Coarse aggregate $\mathrm{MZ}=12.5 \mathrm{~mm}$ & 1.17 \\
Coarse aggregate $\mathrm{MZ}=25 \mathrm{~mm}$ & 1.17 \\
Water & 0.41 \\
Polyfunctional admixture & $0.60 \%$ \\
Superplasticizer admixture & $0.24 \%$ \\
Crystalline waterproofing admixture $^{\mathrm{a}}$ & $0.8 \%$ \\
Silica fume admixture & $10 \%$ \\
\hline
\end{tabular}

a The crystalline waterproofing and silica fume admixtures were not used simultaneously

After molding, the specimens were placed in room temperature within $24 \mathrm{~h}$. Later, they were demolded and stored in a humidity chamber at a temperature of $23 \pm 2$ ${ }^{\circ} \mathrm{C}$ and humidity greater than $95 \%$, where they remained until the tests dates.

\subsubsection{Compressive strength test}

In order to determine the ability to support efforts, it was held the resistance simple compression test, recommended by the NBR 5739 (ABNT) [14].

\subsubsection{Total absorption}

The test was performed as recommended by the NBR 9778 (ABNT) [13], and from its realization was possible to determine the absorption, voids, density of the dry sample, density of the saturated sample and density.

\subsubsection{Under pressure water penetration}

The NBR 10787 (ABNT) [24] presents a test to determine the under pressure water penetration, however, this test requires specific equipment for its realization, and the lack of it in the laboratory has developed an adaptation to 


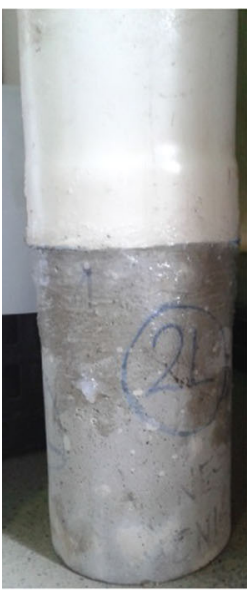

(a)

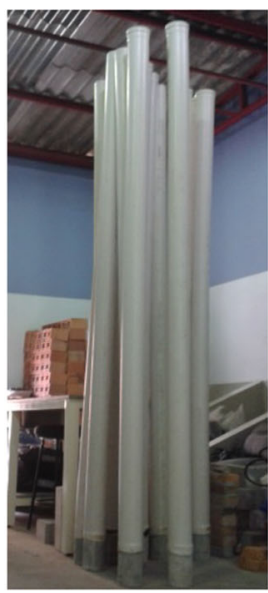

(b)

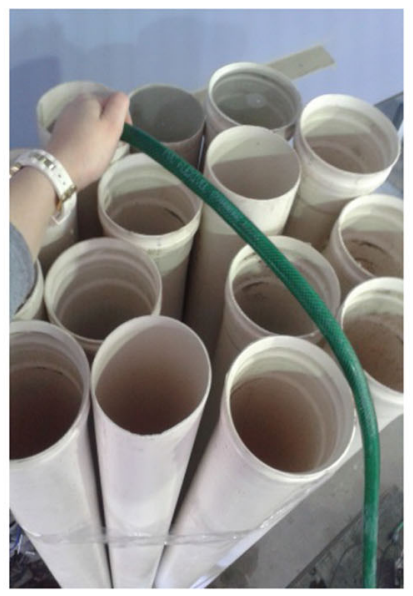

(c)

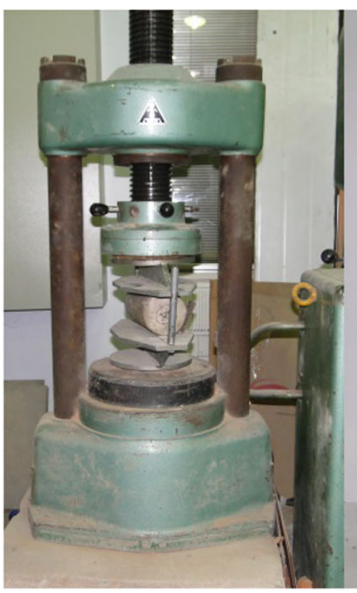

(d)

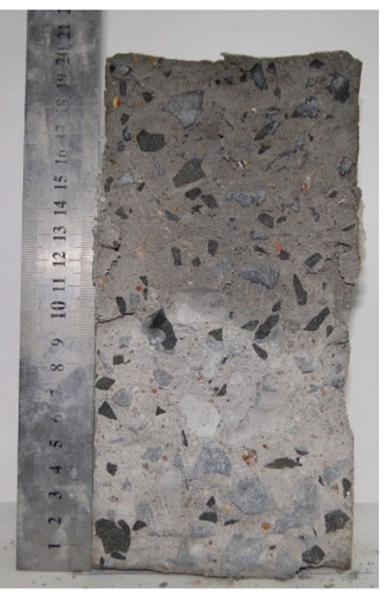

(e)
Fig. 4 Development of under pressure water penetration test a union detail of the specimens with PVC pipe for placement of water, b overview of the specimens, $\mathbf{c}$ filling the water column, $\mathbf{d}$ specimens

evaluate the under pressure water penetration according to the infrastructure available.

There were tested four specimens of each concrete type, which were individually adhered to a PVC pipe with $0.1 \mathrm{~m}$ diameter and $3 \mathrm{~m}$ long, so that one of the pipes ends could be heated and the specimens could be inserted in its inward, and then sealant was spread in the interface (concrete and PVC pipe) to seal it off (Fig. 4a, b).

Then, the PVC pipes were filled with water (Fig. 4c) until the preset level, in this manner was exerted on the specimens upper face concentrated pressure $30 \mathrm{kPa}$. The pressure was kept constant during the week period, and each day the water level was recorded and if necessary, the water was reset to the marked level, thus keeping the water column height at constant pressure.

After a week, the pipes were emptied and the specimens broken by diametrical traction. Then, it was held the photographic record of all samples, these pictures were taken with the same distance, and later to quantify the wet and dried areas (Fig. 4e). Quantitation was performed by using AutoCAD.

\section{Results and discussion}

\subsection{Compressive strength test}

The results of the compressive strength test of the specimens are shown in Table 10. The averages were acquired by breaking seven specimens at age of 28 days.

To study the significance of controllable variables, a variance analysis (ANOVA) was carried out with factor from the software Statistica 7. The results for the compressive strength test at 28 days. Are shown in Table 11. broken by diametrical traction, $\mathbf{e}$ view of the inner face of a specimens after conducting the test

By analyzing the Fig. 5, it can be observed that the use of such waterproofing coating applied by paint practically does not affect the compressive strength compared to the reference concrete. This behavior was expected since the influence of the waterproofing product in this case is only superficial. But when the waterproofing is used as admixture in concrete, it increased its resistance by $16 \%$. This behavior is associated with colmatation of the concrete pores by the waterproofing product. In contrast, the silica fume addition has been proved as the most efficient, as it increased by $28 \%$ the compressive strength in comparison to the reference concrete.

Although it could be observed from the ANOVA, that concrete types variation is a significant factor, it was carried out the analysis using Fisher's F test to see the significance between treatments, which are compared to concrete reference as can be seen in Table 12.

One possible reason for the increase in compressive strength with the waterproofing admixture can be associated with a filler effect that can contribute to close the voids, but can also work as a cement hydration activator by improving the paste cement microstructure, as well as in studies evaluating the mechanical properties of cementitious matrices $[11,12]$. The compressive strength increment demonstrated by the silica fume was already expect, since this is considered a super pozzolan in concrete widely used dosages, required to obtain high strength and/or low capillary porosity $[25,26]$.

\subsection{Total absorption}

\subsubsection{Water absorption and voids}

The results obtained in the test total absorption are presented in Table 13. Averages were obtained by testing four specimens at age of 28 days. 
Table 10 Compressive strength at 28 days of concrete made with different treatments

Table 11 Analysis of variance (ANOVA)-compressive strength at 28 days

\begin{tabular}{llll}
\hline Concrete types & Average resistance (MPa) & SD (MPa) & CV (\%) \\
\hline Reference concrete & 41.551 & 1.433 & 3.448 \\
Crystalline waterproofing coating & 42.861 & 1.305 & 3.044 \\
Crystalline waterproofing admixture & 47.521 & 2.854 & 6.006 \\
Silica fume admixture & 56.646 & 2.198 & 3.880 \\
\hline
\end{tabular}

$S D$ standard deviation, $C V$ coefficient of variation

\begin{tabular}{lrrrrrr}
\hline Effects & QS & DF & MS & Test F & p & Sig. \\
\hline Concrete types & 1010.521 & 3 & 336.840 & 82.205 & 0.000000 & Yes \\
Error & 102.439 & 25 & 4.098 & & & - \\
\hline
\end{tabular}

$Q S$ quadratic sum, $D F$ degrees of freedom (n-1), $M S$ mean square, Test $\mathrm{F}$ (calc): calculated value $\mathrm{F}, \mathrm{p}$ significance level, if $\mathrm{p}<5 \%=$ significant effect

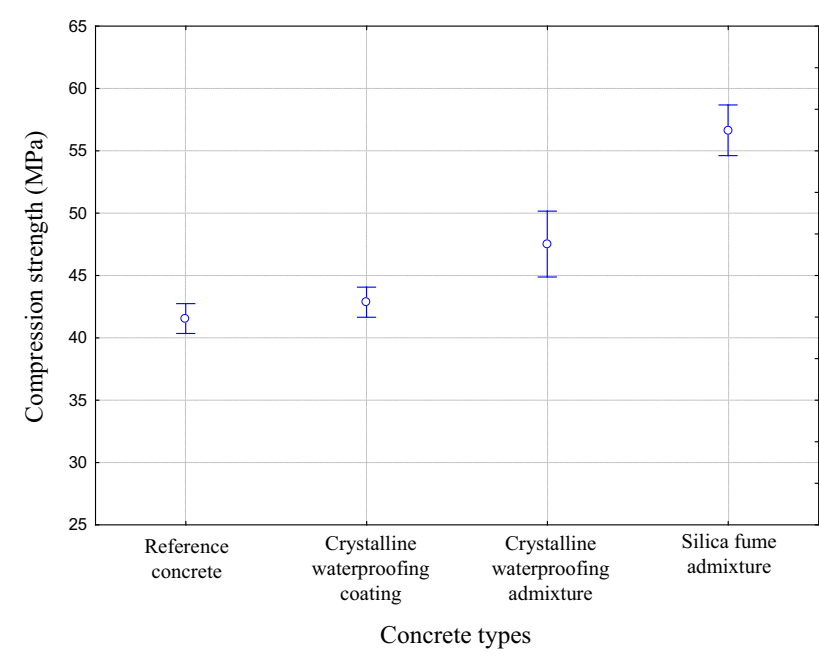

Fig. 5 Compression strength of concrete at 28 days

To study the significance of controllable variables, a variance analysis (ANOVA) was carried out with factor from the software Statistica 7. The results are shown in Table 14, for the water absorption test at 28 days.

By analyzing the Fig. 6, it can be observed that the use of crystalline waterproofing coating reduces the water absorption both for samples that have undergone the sanding process and the ones that haven't. The crystalline waterproofing admixture increased water absorption compared to the reference concrete. This may be linked to a change in the size of the concrete capillary pores. However, the silica fume admixture was more efficient than other methods, since it showed the greatest reduction in water absorption.

Although it was observed from the ANOVA, that variation concrete types is a significant factor, it was carried out by Fisher's $F$ test to see significance between variation concrete types, which are compared to reference concrete as it can be seen in Table 15 .

The water absorption reduction displayed by the concrete with the silica fume admixture was expected, since this admixture has the characteristic of improving the matrix properties, mainly high initial resistance or low penetration [26]. It is noteworthy that the improved properties are not only the pozzolanic effect (chemical) that silica fume presents, but also the filler effect (physical) by fine particles, both contribute to the formation of a concrete with better microstructure [26]. The physicochemical effect is also described as an influence so is the exudate decreased, the size voids and volume reduction, better cohesion due to fine particles, increase in packing factor and consequent enhanced resistance [5].

It is observed that the use of crystalline waterproofing coating is more efficient compared with the crystalline waterproofing admixture. It is believed that this occurred because the crystalline waterproofing coating are materials that show as background the cement, added to resin and applied in paste form, which penetrates the pores of the surface, crystallizing and buffering [27]. In this way are

Table 12 Fisher's F test for compression strength at 28 days

\begin{tabular}{llll}
\hline & Crystalline waterproofing coating & Crystalline waterproofing admixture & Silica fume admixture \\
\hline Reference concrete & NS & S & S \\
\hline
\end{tabular}

$N S$ not significant, $S$ significant 
Table 13 Water absorption and voids of concrete types

\begin{tabular}{|c|c|c|c|c|c|c|}
\hline \multirow[t]{2}{*}{ Concrete types } & \multicolumn{3}{|c|}{ Water absorption } & \multicolumn{3}{|l|}{ Voids } \\
\hline & Average & SD & $\mathrm{CV}$ & Average & SD & $\mathrm{CV}$ \\
\hline Reference concrete & 5.960 & 0.236 & 3.962 & 13.303 & 0.471 & 3.540 \\
\hline Crystalline waterproofing coating & 5.323 & 0.140 & 2.623 & 12.005 & 0.259 & 2.161 \\
\hline Crystalline waterproofing coating and sanding & 5.363 & 0.396 & 7.385 & 12.042 & 0.728 & 6.044 \\
\hline Crystalline waterproofing admixture & 6.141 & 0.428 & 6.969 & 14.037 & 0.893 & 6.365 \\
\hline Silica fume admixture & 4.992 & 0.292 & 5.849 & 11.291 & 0.612 & 5.422 \\
\hline
\end{tabular}

$S D$ standard deviation, $C V$ coefficient of variation
Table 14 Analysis of variance (ANOVA)-water absorption

\begin{tabular}{llrllll}
\hline Effects & QS & DF & MS & Test F & p & Sig. \\
\hline Concrete types & 3.659 & 4 & 0.915 & 9.139 & 0.000602 & Yes \\
Error & 1.502 & 15 & 0.100 & & & - \\
\hline
\end{tabular}

$Q S$ quadratic sum, $D F$ degrees of freedom (n-1), $M S$ mean square, Test F (calc): calculated value F, p significance level, if $\mathrm{p}<5 \%=$ significant effect

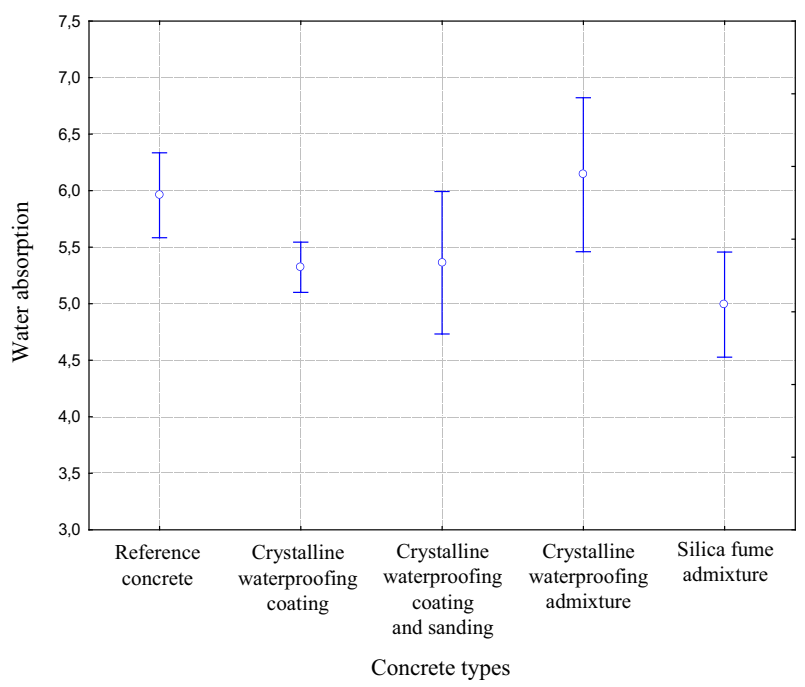

Fig. 6 Water absorption at 28 days

regarded as pores patch protection system, causing the closure of pores [10], since due to the silicate-based substances present in the product to penetrate the concrete react with the byproducts thereof, in particular the calcium hydroxide, and form crystals that cause pore buffering.

The absorption and voids increase in the concrete with the crystalline waterproofing admixture can be justified by a possible hygroscopicity generated by the use of this product may be a result of increase porosity or amount of evenly distributed small pores, or by the product may be hygroscopic and contribute to this increase absorption. In this case, it would take specific tests to prove this hypothesis. Some studies have reported a reduction in the size of pores of the concrete with the use of added sodium silicate base for developing the concrete waterproofing [28]. The fact that the compressive strength is higher than the specific reference may be justified because for a given porosity, smaller pores resulting in a higher strength cement paste [26].

It is observed that the use of crystalline waterproofing coating is more efficient compared with the concrete with waterproofing admixture. The crystalline waterproofing coating system is a form of surface protection and has little dependence on the distribution of concrete voids, because it was expected to have better performance than the reference concrete [29].

Thus, as water absorption was taken to analyze the significance of controllable variables, it was performed an Analysis of Variance (ANOVA) with factor from software Statistica 7. The results are shown in Table 16 for the voids.

By analyzing the Fig. 7 it can also be observed that the voids show the same behavior as the water absorption, so the analysis are also the same.

\subsubsection{Bulk specific gravity}

With total absorption test it is also possible to calculate the bulk specific gravity, and the density of the dry sample, density of the saturated sample and the specific mass. However, analyzing Table 17 it can be realized that these were not significant differences.

\subsection{Under pressure water penetration}

By this test it is possible to analyze the concrete permeability. Table 18 gives average wet areas of the four specimens tested for each concrete type studied, and Fig. 8 graph with the results.

It can also be seen that the concrete which received the crystalline waterproofing coating, such as painting, did not allow the steam passage, retaining fluid throughout specimen, that was not expected, since the function of 
Table 15 Fisher's F test for water absorption

\begin{tabular}{lllll}
\hline & $\begin{array}{l}\text { Crystalline waterproofing } \\
\text { coating }\end{array}$ & $\begin{array}{l}\text { Crystalline waterproofing coating } \\
\text { and sanding }\end{array}$ & $\begin{array}{l}\text { Crystalline waterproofing } \\
\text { admixture }\end{array}$ & $\begin{array}{l}\text { Silica fume } \\
\text { admixture }\end{array}$ \\
\hline $\begin{array}{c}\text { Reference } \\
\text { concrete }\end{array}$ & NS & NS & S & S \\
\hline
\end{tabular}

$N S$ not significant, $S$ significant

Table 16 Analysis of variance (ANOVA)-voids

\begin{tabular}{lrrllll}
\hline Effects & QS & DF & MS & Test F & psss & Sig. \\
\hline Concrete types & 19.666 & 4 & 4.917 & 12.343 & 0.000122 & Yes \\
Error & 5.975 & 15 & 0.398 & - & - & - \\
\hline
\end{tabular}

$Q S$ quadratic sum, $D F$ degrees of freedom (n-1), $M S$ mean square, Test F (calc): calculated value F, p significance level; if $\mathrm{p}<5 \%=$ significant effect

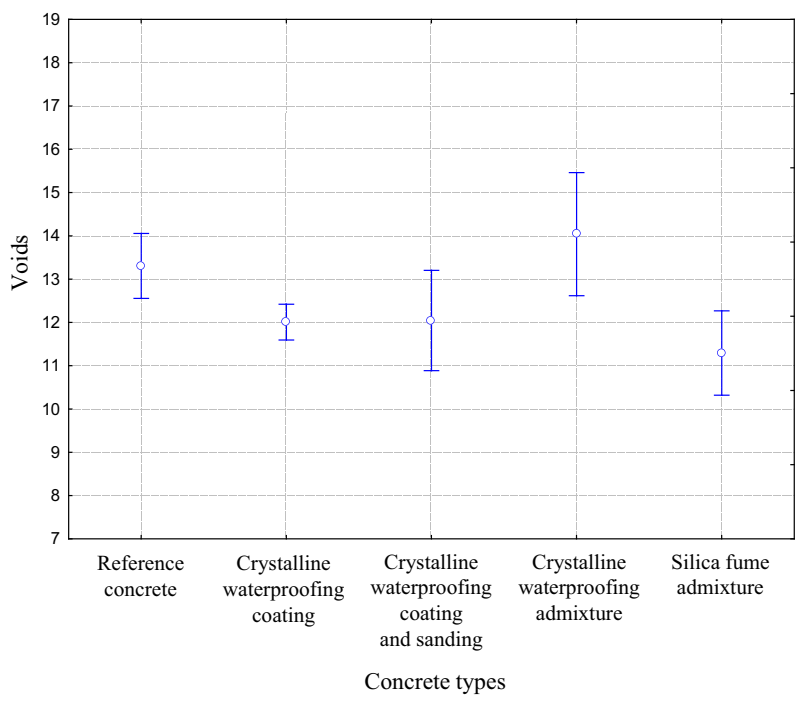

Fig. 7 Voids at 28 days

crystalline waterproofing is to prevent the water penetration and allow the steam passage. However, the concrete which received the crystalline waterproofing coating as painting and passed after manual sanding process, allowed steam evaporation absorbed during the test. Soon the sanding is beneficial because it allows the steam permeability.

When analyzed, using the crystalline waterproofing admixture, it also allowed the evaporating steam as well as silica fume admixture, however, this is more efficient. Whereas, if analyze only the use of crystalline waterproofing from variations of uses, it is noted that the application by painting is more efficient than admixture, since the painting receives sanding process.

To study the significance of controllable variables (concrete types) a variance analysis (ANOVA) was carried out with factor from the software Statistica 7 . The results are shown in Table 19, for the under pressure water penetration test.

Although from the ANOVA was observed that variation concrete types is a significant factor, it was carried out the analysis using Fisher's F test to see significance between concrete types variation, which are compared to reference concrete as can be seen in Table 20.

From Fisher's F test it was found that only with crystalline waterproofing coating concrete was significantly different, because it was the only one, which did not allow steam evaporation, and thus had a completely wet area.

\section{Conclusions}

According to the study that examined the capillary porosity concrete by means of experimental methods: total absorption-NBR 9778 (ABNT), under pressure penetration water $(30 \mathrm{kPa})$, and in parallel the compressive strength test-NBR 5739 (ABNT), it was found that the
Table 17 Bulk specific gravity $\left(\mathrm{g} / \mathrm{cm}^{3}\right)$

\begin{tabular}{llll}
\hline Concrete types & \multicolumn{3}{l}{ Average bulk specific gravity $\left(\mathrm{g} / \mathrm{cm}^{3}\right)$} \\
\cline { 2 - 4 } & Dry sample & Saturated sample & Density \\
\hline Reference concrete & 2.233 & 2.366 & 2.575 \\
Crystalline waterproofing coating & 2.256 & 2.376 & 2.563 \\
Crystalline waterproofing coating and sanding & 2.247 & 2.368 & 2.555 \\
Crystalline waterproofing admixture & 2.286 & 2.427 & 2.660 \\
Silica fume admixture & 2.262 & 2.375 & 2.550 \\
\hline
\end{tabular}


Table 18 Average the wet area of under pressure water penetration

\begin{tabular}{lllr}
\hline Concrete types & \multicolumn{3}{l}{ Under pressure water penetration } \\
\cline { 2 - 4 } & Average wet area $(\%)$ & SD (\%) & CV (\%) \\
\hline Reference concrete & 57.496 & 9.166 & 15.941 \\
Crystalline waterproofing coating & 100.000 & 0.000 & 0.000 \\
Crystalline waterproofing coating and sanding & 53.045 & 3.899 & 7.350 \\
Crystalline waterproofing admixture & 63.844 & 1.502 & 2.352 \\
Silica fume admixture & 51.904 & 2.960 & 5.703 \\
\hline
\end{tabular}

$S D$ standard deviation, $C V$ coefficient of variation

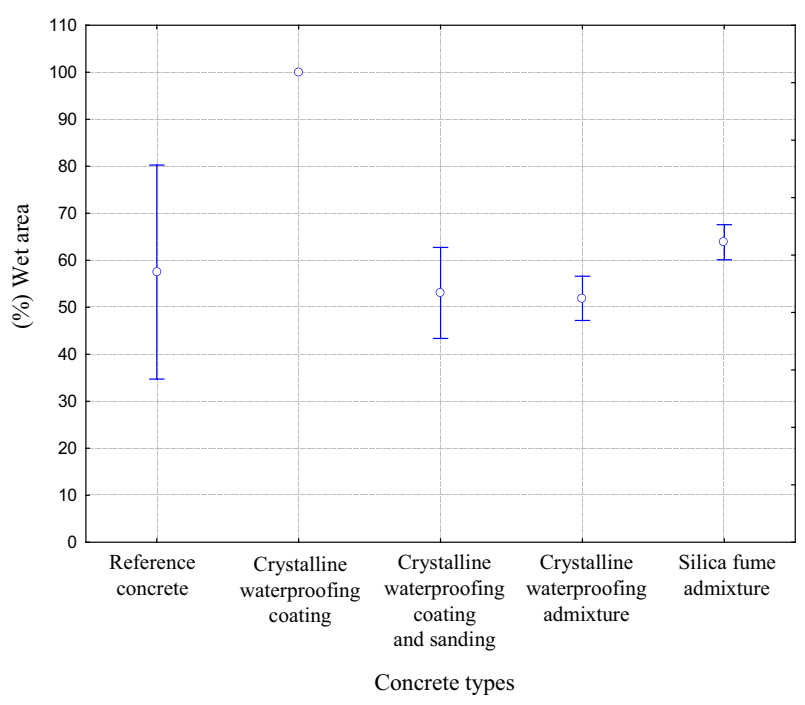

Fig. 8 Under pressure water penetration

Table 19 Analysis of variance (ANOVA)-under pressure water penetration

\begin{tabular}{llrllll}
\hline Effects & QS & DF & MS & Test F & p & Sig. \\
\hline Concrete types & 0.496 & 4 & 0.124 & 59.478 & 0.000000 & Yes \\
Error & 0.0229 & 11 & 0.002 & & & - \\
\hline
\end{tabular}

$Q S$ quadratic sum, $D F$ degrees of freedom (n-1), $M S$ mean square, Test F (calc): calculated value F, p significance level; if $\mathrm{p}<5 \%=$ significant effect

Table 20 Fisher's F test for under pressure water penetration

\begin{tabular}{lllll}
\hline & $\begin{array}{l}\text { Crystalline } \\
\text { waterproofing } \\
\text { coating }\end{array}$ & $\begin{array}{l}\text { Crystalline } \\
\text { waterproofing } \\
\text { coating and } \\
\text { sanding }\end{array}$ & $\begin{array}{l}\text { Crystalline } \\
\text { waterproofing } \\
\text { admixture }\end{array}$ & $\begin{array}{l}\text { Silica } \\
\text { fume } \\
\text { admixture }\end{array}$ \\
\hline $\begin{array}{r}\text { Reference } \\
\text { concrete }\end{array}$ & S & NS & NS & NS \\
\hline
\end{tabular}

$N S$ not significant, $S$ significant silica fume admixture was the solution with the best performance, increasing compressive strength, reducing water absorption and void. Since the crystalline waterproofing for the compressive strength test proved effective when used as admixture in the concrete, but does not influence the resistance when applied as coating. The use of crystalline waterproofing coating reduces the water absorption both for the samples which have undergone the sanding process and the ones that have not, since it also reduces void levels. However, no significant influence on the compressive strength was noted. In total absorption assays and under pressure water penetration, it was noted that the sanding process is beneficial for the performance of the crystalline waterproofing coating, and that the use is more efficient compared with crystalline waterproofing admixture. The crystalline waterproofing admixture increased water absorption compared to the reference concrete, this fact may be associated with a variation in the capillary pores dimension of the concrete due to the use of the waterproofing product, absorption is directly linked to voids, so if there was a greater absorption there is also increase in voids. However, this was not expected since the compressive strength test of the crystalline waterproofing admixture contributed to a significant increase. The performance of this product was not suitable to the expected product as by increasing the concrete voids with crystalline waterproofing admixture may have contributed to increase hygroscopicity of the material. Thus, the crystalline waterproofing in most cases performed better than reference concrete, but when it is compared with the silica fume admixture to the material and proportions studied, it appears that the use of silica fume admixture was the best solution for reducing capillary porosity.

Acknowledgements We want to thank the company Queiroz Galvao for donating the materials used in this study and the Center for Innovation Oriented Building (NORIE) for providing the Materials and Technology Laboratory of the Built Environment (LAMTAC) for the research. 


\section{References}

1. Andrade T (2005) Topics Concrete Durability. Concrete: Education Research and Achievements, cap 25, 1st edn. IBRACON, São Paulo, pp 753-792

2. Ribeiro DV et al (2014) Corrosion in Reinforced concrete structures: theory, control and analysis methods, cap 3, 1st edn. Elsevier, Rio de Janeiro, p 38

3. Andrade JJO (1997) Concrete structures durability armed: analysis of pathological manifestations in the structures in the state of pernambuco. Federal University of Rio Grande do Sul, Porto Alegre, p 148

4. John VM (2000) Recycling of waste in construction: contribution to research and development Methodology. Polytechnic School of the University of São Paulo, São Paulo, p 113

5. Mehta PK, Monteiro PJM (2014) Concrete: structure, properties and materials, cap 5, 2nd edn. IBRACON, São Paulo, p 125

6. Aitcin PC (2003) The durability characteristics of high performance concrete: a review. Cement Concr Compos 25(4-5):409-420

7. Andrade C (1992) Manual for Deteriorated Works Diagnostic Corrosion Armor. PINI, São Paulo, p 103

8. Possan E (2010) Modeling carbonation and prediction of service life of concrete structures in urban environment. Federal University of Rio Grande do Sul, Porto Alegre, p 265

9. Muhammad N, Keyvanfar A, Majid M, Mirza AJ (2015) Waterproof performance of concrete: a critical review on implemented approaches. Constr Build Mater 101:80-90

10. Bertolini L (2010) Building materials: pathology, rehabilitation and prevention. P Oficina de Textos, HELENE

11. Li H, Xiao J, Yuan J, Ou J (2004) Microstructure of cement mortar with nanoparticles. Compos Part B Eng 35(2):185-189

12. ASSOCIAÇÃO BRASILEIRA DE NORMAS TÉCNICAS (2009) NBR 9778: Hardened mortar and concrete-Determination of absorption, voids and specific gravity. Rio de Janeiro

13. ASSOCIAÇÃO BRASILEIRA DE NORMAS TÉCNICAS (2007) NBR 5739: Concrete-Compression test of cylindric specimens-method of test. Rio de Janeiro

14. ASSOCIAÇÃO BRASILEIRA DE NORMAS TÉCNICAS (1991) NBR 5736: Pozzolanic Portland cement-Specification. Rio de Janeiro

15. AMERICAN SOCIETY FOR TESTING AND MATERIALS (2003) ASTM C 595: Standard Specification for Blended Hydraulic Cements. West Conshohocken

16. Neville A (1997) Concrete properties. In: PINI, 2nd edn. São Paulo, p 828.
17. ASSOCIAÇÃO BRASILEIRA DE NORMAS TÉCNICAS (2001) NBR NM 23: Portland cement and other powdered material-Determination of density. Rio de Janeiro

18. ASSOCIAÇÃO BRASILEIRA DE NORMAS TÉCNICAS (2003) NBR NM 248: Aggregates-Sieve analysis of fine and coarse aggregates. Rio de Janeiro

19. ASSOCIAÇÃO BRASILEIRA DE NORMAS TÉCNICAS (2009) NBR NM 52: Fine aggregate-Determination of the bulk specific gravity and apparent specific gravity. Rio de Janeiro

20. ASSOCIAÇÃO BRASILEIRA DE NORMAS TÉCNICAS (2009) NBR NM 53: Coarse aggregate-Determination of the bulk specific gravity, apparent specific gravity and water absorption. Rio de Janeiro

21. ASSOCIAÇÃO BRASILEIRA DE NORMAS TÉCNICAS (2009) NBR 7211: Aggregates for concrete-Specification. Rio de Janeiro

22. ASSOCIAÇÃO BRASILEIRA DE NORMAS TÉCNICAS (2015) NBR 5738: Concrete-Procedure for molding and curing concrete test specimens. Rio de Janeiro

23. ASSOCIAÇÃO BRASILEIRA DE NORMAS TÉCNICAS (1998) NBR NM 67: Concrete-Slump test for determination of the consistency. Rio de Janeiro

24. ASSOCIAÇÃO BRASILEIRA DE NORMAS TÉCNICAS (2011) NBR 10787: Hardened concrete-Determination of water penetration under pressure. Rio de Janeiro

25. Helene P, Andrade T (2010) Portland cement concrete. In: Isaia GC (ed) Construction materials and principles of materials science and engineering. Ibracon, São Paulo

26. Neville AM (2016) Concrete properties. In: Cremonini RA (ed) (Tradução), 5th edn. Bookman, Porto Alegre

27. Souza JCS, Melhado SB (1998) General considerations on the waterproofing systems of pavement floors: type of buildings. (Technical Bulletin of the Polytechnic School of USP, Department of Engineering, Construction,BT/PCC/196). EPUSP, São Paulo, p 31

28. Song Z, Xue X, Li Y, Yang J, He Z, Shen S, Jiang L, Zhang W, Xu L, Zhang H, Qu J, Ji W, Tao Z, Huo L, Wang B, Lin X, Zhang $N$ (2016) Experimental exploration of the waterproofing mechanism of inorganic sodium silicate-based concrete sealers. Constr Build Mater 104:276-283

29. Zhang P, Wittmann FH, Villmann B, Zhao TJ, Slowik V (2008) Moisture diffusion in and capillary suction of integral water repellent cement based materials. 5th International Conference on Water Repellent Treatment of Building Materials. Hydrophobe V. Aedificatio Publishers, Brussels, pp 273-286 